\title{
EFFICIENCY ANALYSIS OF THE SOLAR TRACKING PV SYSTEMS IN ESKIŞEHIR REGION
}

\author{
Tansu FİLIKK ${ }^{1, *}$, Ümmühan BAŞARAN FİLİK ${ }^{1}$ \\ ${ }^{1}$ Department of Electrical and Electronics Engineering, Faculty of Engineering, Anadolu University, \\ Eskişehir, Turkey
}

\begin{abstract}
In this study, efficiency analysis of the solar tracking photovoltaic (PV) system in Eskişehir region is considered for onsite real solar power generation values. It is shown that the tracking system's power generations are always higher than fixed one, but increased yield ratio is changing according to weather conditions (sunny or cloudy times). In order to make a fair analysis/comparison, all the instantaneous real solar power generations between 1 July and 30 October 2016 are used to figure out the ratio of sunny and cloudy days of the whole year. The averaged total generation values are calculated and it is revealed that the tracking system provides approximately $33 \%$ higher electricity generation than the same capacity fixed PV panels for Eskişehir region.
\end{abstract}

Keywords: Sun tracking PV system, Solar energy, Photovoltaic, Fixed PV panels, Efficiency analysis

\section{INTRODUCTION}

Many countries around the world are increasing the amount of renewable energy while improving the energy efficiency [1]. Since solar energy is sustainable, emission-free and cost-effective, it is a promising source for clean energy production [2-4]. Photovoltaic (PV) solar panel systems convert sun lights to electricity. The total amount of average solar irradiation value is most important indicator to determine the total energy generation from sun. This value changes according to location of the region (distance from the sun). Depending on the arrival angle of the sun lights, the amount of the converted energy on PV panels varies. To obtain highest energy from sun, different types of sun tracker systems that change in terms of functions, complexity and also cost can be used [5]. Single-axis tracker, and double axis tracker systems are generally used to track of the sun mechanically. The main difference of these systems is double axis tracker system both follow the sun from east to west through daily path and with tilt angle changing of the modules according to seasons.

In this study, the real instantaneous power generation values (in Watt) of sun tracking and fixed solar PV systems with same capacity $(3 \mathrm{~kW})$ are collected for Eskişehir region. To our knowledge, the collected power real generation values of fixed and solar tracking system is unique for the selected region (Central Anatolia, Eskişehir). In the literature, there are limited studies which compare/analyze fixed and tracking solar PV systems with real power generation values. Eke and Senturk [6] performed double-axis sun tracker system with fixed PV system at Muğla University and achieved nearly 30\% output power increase by using double-axis tracking system. Senpinar and Cebeci [7] compared the performance of two PV modules with one fixed and two-axis tracking system at Firat University. They are reported that the tracking system offers between $13 \%$ to $15 \%$ higher power generation capacity than the fixed modules. Eldin et al [8] searched the feasibility of solar tracking system in hot and cold regions. Dakkak and Babeli in [9] presented a cost analysis of fixed and tracking systems. In [10-13], there are some important studies which analyze and report performance and cost differences between tracking and fixed solar PV panels. 
As is known, the sun tracker system generates higher energy than a fixed system because of direct exposure to sunlight. The over generation value is directly related with geographic location and maximum temperature values of the sun tracking system. According to studies, the total yield from the sun tracking system can be increased approximately 39\% especially in cold (bud sunny) cities such as Berlin, Germany, however the amount of the total energy for hot cities such as Aswan, Egypt does not exceed 8\% due to overheating of solar panels [5]. The aim of this study is to present the feasibility (provided yield in percentage) of commercial off-the-shelfs (COTS) sun tracker systems (Lorentz Etatract) for Eskişehir, Turkey.

The remaining parts of the paper are organized as follows. In Section 2, the description of the corresponding PV systems which are constructed on a hybrid renewable smart home energy system is introduced. In Section 3, the collected real power generation values of the system with respect to time is presented and classified for sunny, cloudy and partly cloudy days. Performance results are discussed of solar tracker systems in Section 4. Finally, in Section 5, the main contributions of this paper are highlighted and possible research directions are discussed.

\section{SOLAR POWER GENERATION SYSTEM}

In this study, real solar PV panel's energy generation from sun tracking and fixed platforms with same capacity are measured/collected for cost and potential analysis of these two systems in Eskisehir region of Turkey. Eskişehir is located 39.78 latitude and 30.52 longitude and it is situated at elevation 794 meters above sea level. In order to monitor, analyze and model the renewable energy potentials of the Eskisehir region; solar panels, wind turbines, domestic load monitoring and multichannel data acquisition systems are established in Renewable Energy Research Laboratory (RERL) in Iki Eylul Campus of Anadolu University (Eskisehir) which are shown in Figure 1.

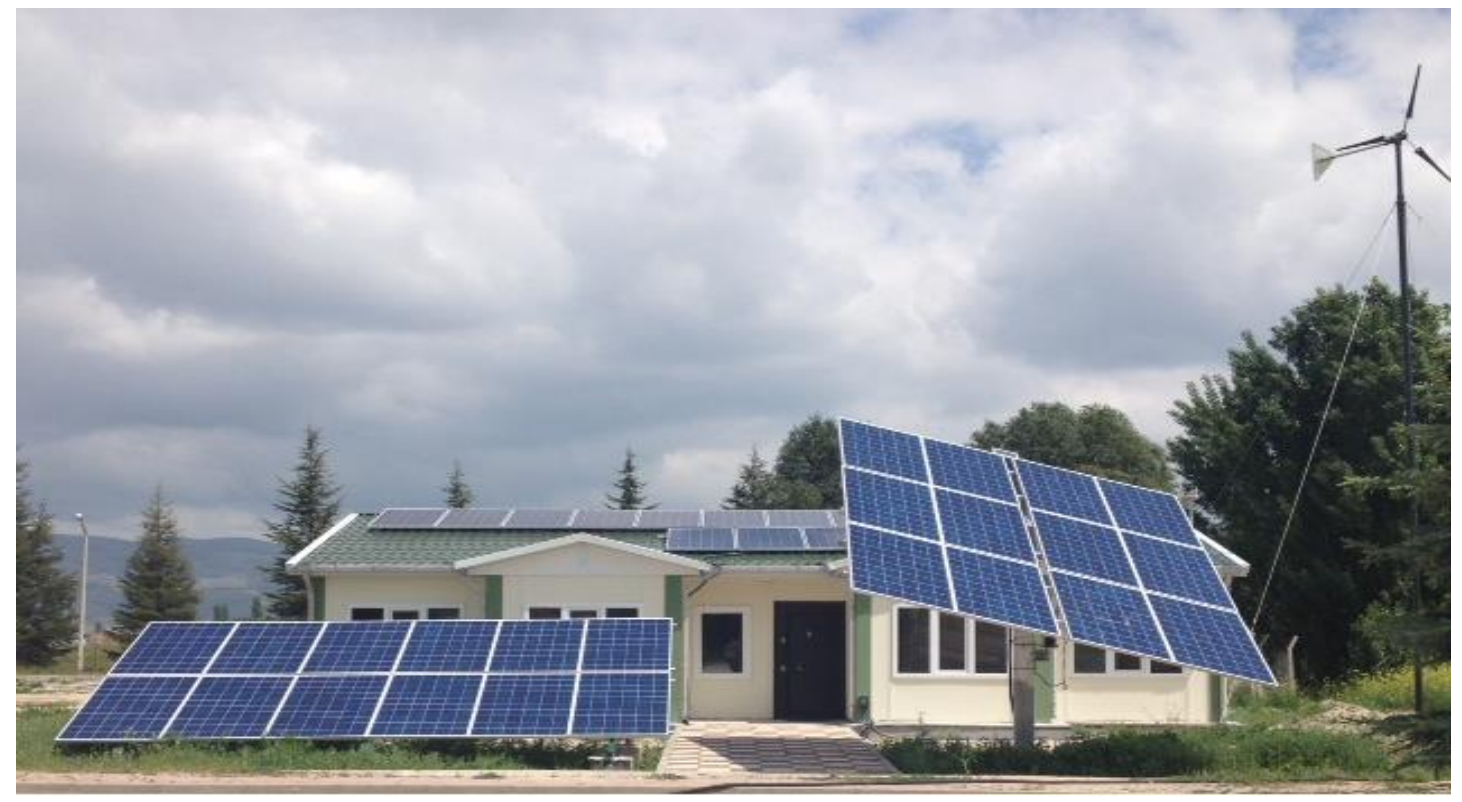

Figure 1. Renewable energy research laboratory in Anadolu University İki Eylul Campus of Eskişehir

In solar energy generation system 39 solar PV panels with $260 \mathrm{~W}$ capacity are used. The overall energy generation system is established as a hybrid renewable energy system which consists of both 6 $\mathrm{kW}$ on-grid (3 kW fixed on the ground, $3 \mathrm{~kW}$ solar tracker) and $4 \mathrm{~kW}$ off-grid (roof mounted) solar panels additionally $1 \mathrm{~kW}$ wind turbine. The general structure of the solar energy generation system is given in Figure 2. 
$3 \mathrm{~kW}$ (12 panels with $260 \mathrm{~W}$ capacity) active tracking system which can be seen on the right hand side of the Figure 1 and $3 \mathrm{~kW}$ (12 panels with $260 \mathrm{~W}$ capacity) fixed system which is on the left hand side of the Figure 1 are established with the equivalent PV panels. $260 \mathrm{~W}$ capacity PV panel's technical specifications are summarized in Table 1.

Table 1. Electrical data of the used panel (at standard conditions (STC) irradiance 1000 watt $/ \mathrm{m}^{2}$, spectrum AM 1.5 at a cell temperature of $25^{\circ} \mathrm{C}$ )

\begin{tabular}{|l|l|l|l|l|l|l|}
\hline Type & $\begin{array}{l}\text { Nominal } \\
\text { output } \\
\text { Pmpp }\end{array}$ & $\begin{array}{l}\text { Nominal } \\
\text { voltage } \\
\text { Umpp }\end{array}$ & $\begin{array}{l}\text { Nominal } \\
\text { current } \\
\text { Impp }\end{array}$ & $\begin{array}{l}\text { Short circuit } \\
\text { current } \\
\text { Isc }\end{array}$ & $\begin{array}{l}\text { Open } \\
\text { circuit } \\
\text { voltage } \\
\text { Uoc }\end{array}$ & $\begin{array}{l}\text { Module } \\
\text { conversion } \\
\text { efficiency }\end{array}$ \\
\hline AC-260P/156-60S & $260 \mathrm{Wp}$ & $30,92 \mathrm{~V}$ & $8,43 \mathrm{~A}$ & $9,01 \mathrm{~A}$ & $38,00 \mathrm{~V}$ & $15,98 \%$ \\
\hline
\end{tabular}

Tracking system follow the sun through the day, this extends the time that useful power levels are delivered and maximizes the peak power. The tracker system's technical specifications can be summarized as, single axis, $90^{\circ}$ tracking angle east-west, robust hot zinc-coated steel frame, for ground installation on concrete foundation, stainless steel module fixings, maintenance-free DC linear drive, sensorless control, and self-powered with very low energy consumption and the most important parameters of used tracker are, single axis design for cost effectiveness, reliability and efficiency, simple design for fast, failure-free installation, high reliability and excellent serviceability lowers cost of ownership, long life expectancy in line with PV modules for predictable financial planning, short Return of Investment (ROI) cycle, very attractive business case against fixed and dual axis PV installations. In this study, tracking system is used in its automatic mode where panels move in 12 equal steps to the west position, which results with very low energy consumption. It is also possible to define manual tracking steps with minute resolutions which increase the energy consumption of the system for tracking. But the manufacturer is not guaranteed uninterrupted tracking in manual mode and when the internal battery level of the linear actuator falls below a certain value, the systems quits tracking.

The instantaneous power generation values (in Watt) of the tracker and fixed PV panels are recorded in 5 minutes' intervals with solar log system which is connected to on-grid inverter. The overall structure and electrical connections of the off-grid, on-grid inverters, instantaneous solar power recording system and batteries are shown in Figure 2.

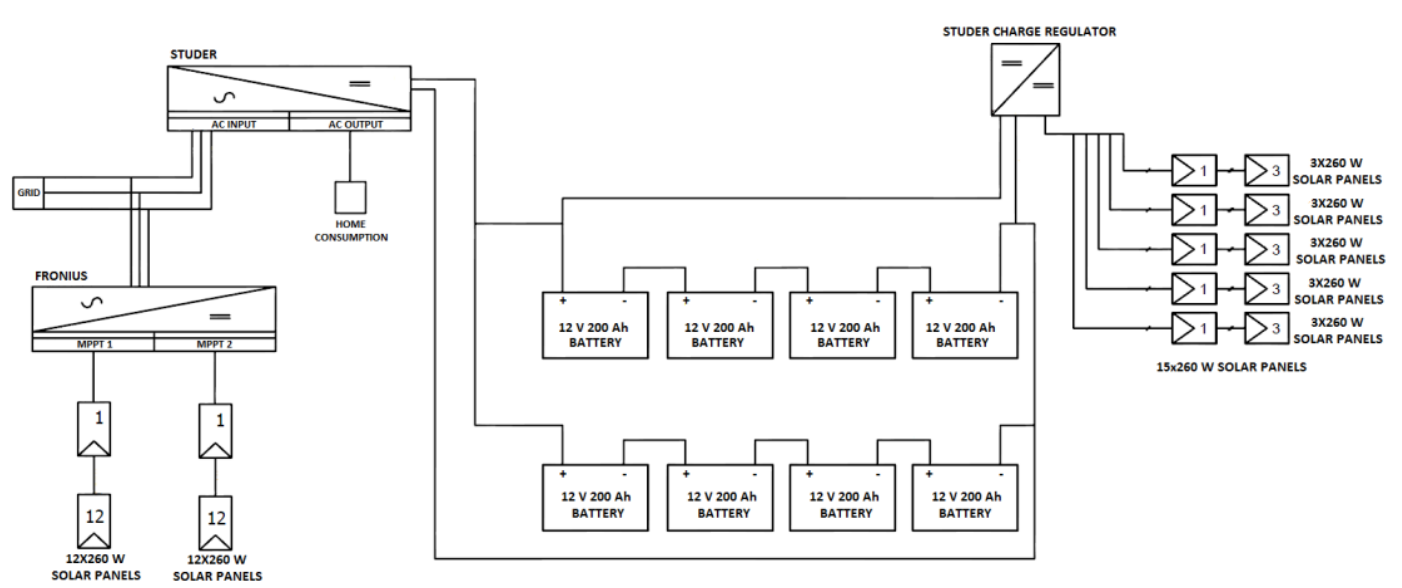

Figure 2. The overall structure and electrical connections of the off grid, on grid inverters, instantaneous solar power recording system and batteries 


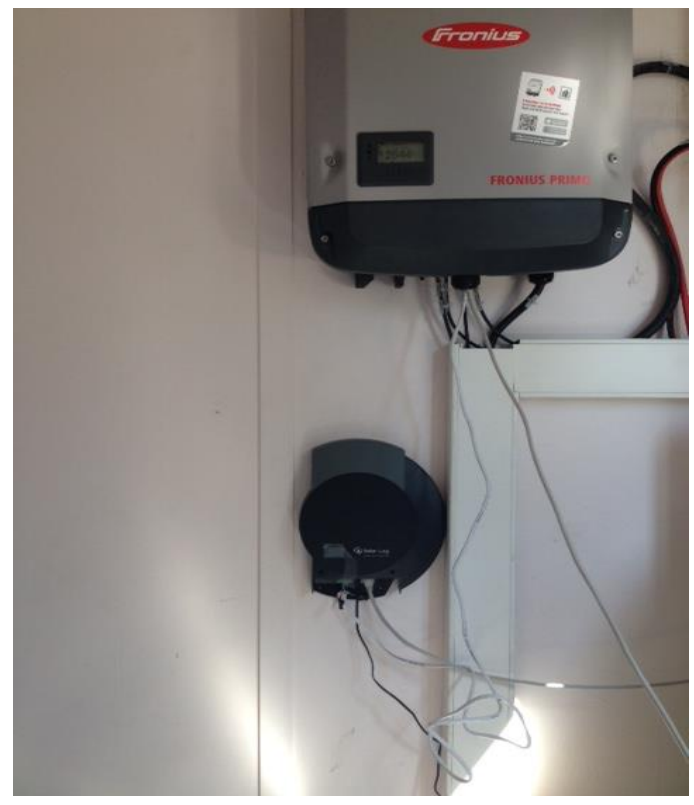

Figure 3. Solar-log device and on grid inverter

Figure 3 shows the solar-log device which is connected to the on grid Fronius Inverter.

On and off grid inverters are shown in Figure 4(a), (b), respectively. The solar log system is connected to Fronius (off-grid) inverter in order to monitor and record the instantaneous output power of the fixed and one - axis tracker system. By using this equipment, the output power generation values (in Watt) can be recorded with five-minute intervals.

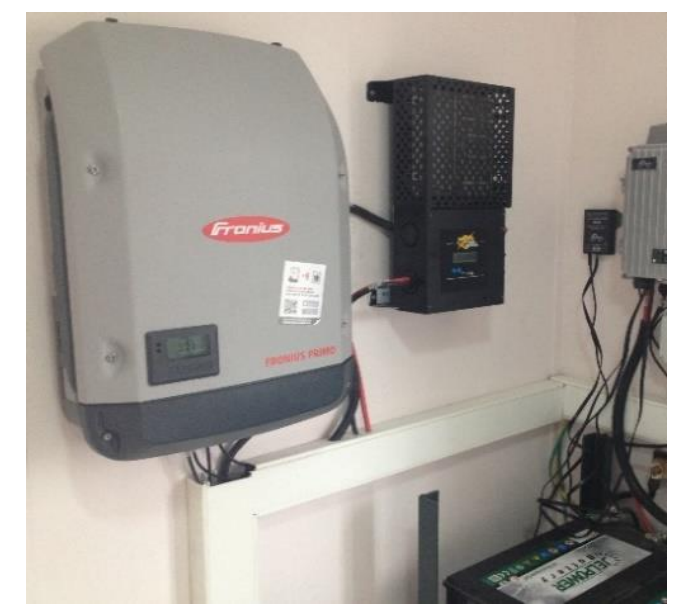

Figure 4. (a). On-grid Inverter (Fronius)

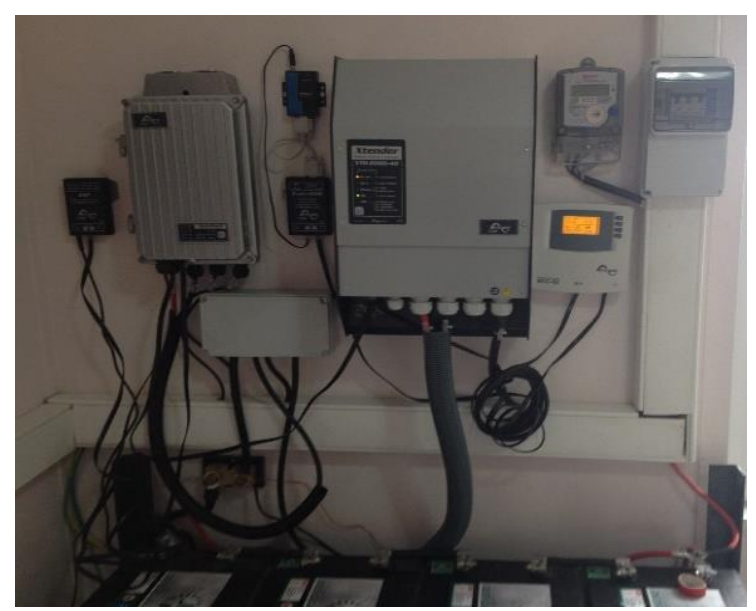

Figure 4. (b). Off Grid Inverter (Studer)

\section{DATA ANALYSIS}

In this study, tracking and fixed PV solar power generation values are recorded with 5 minutes' intervals between 1 July and 30 October 2016. Figure 5 and Figure 6 shows instantaneous power generation values versus time data for 70 days of tracking and fixed system respectively. 


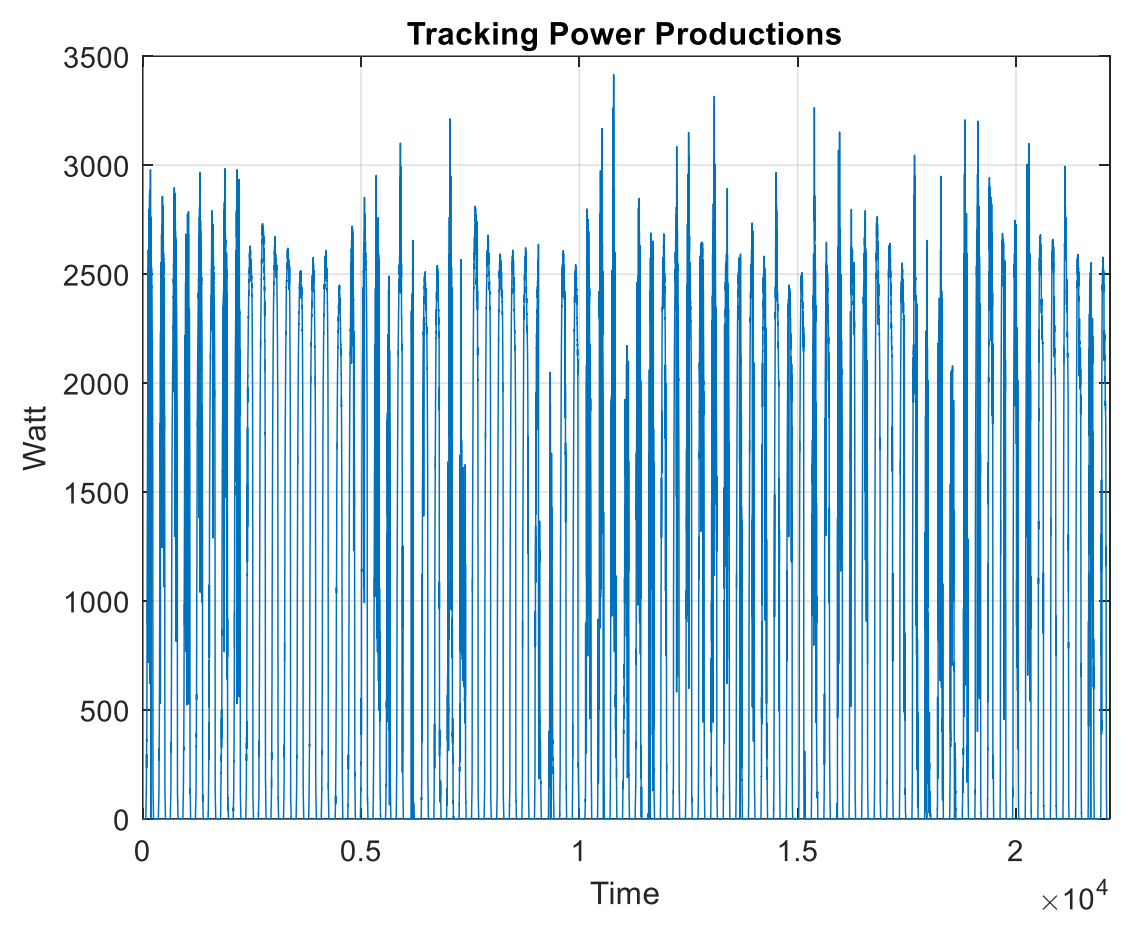

Figure 5. Power generation of tracking system

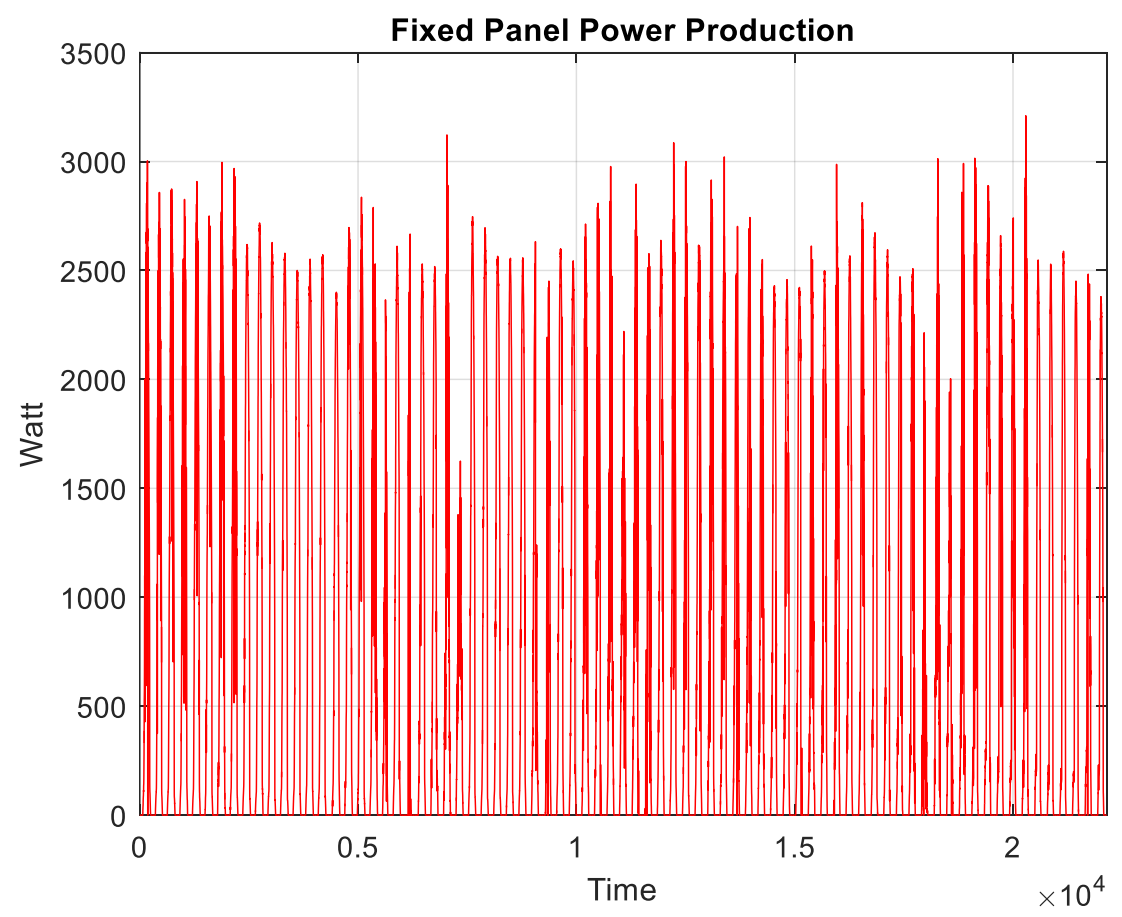

Figure 6. Power generation of fixed system

Tracking and fixed system's annual power generation values for an example sunny day on $12^{\text {th }}$ July 2016 is given in Figure 7. As it is seen, tracking system have wider peak and useful power level interval than fixed system for all day which provide approximately $40 \%$ higher yield. 


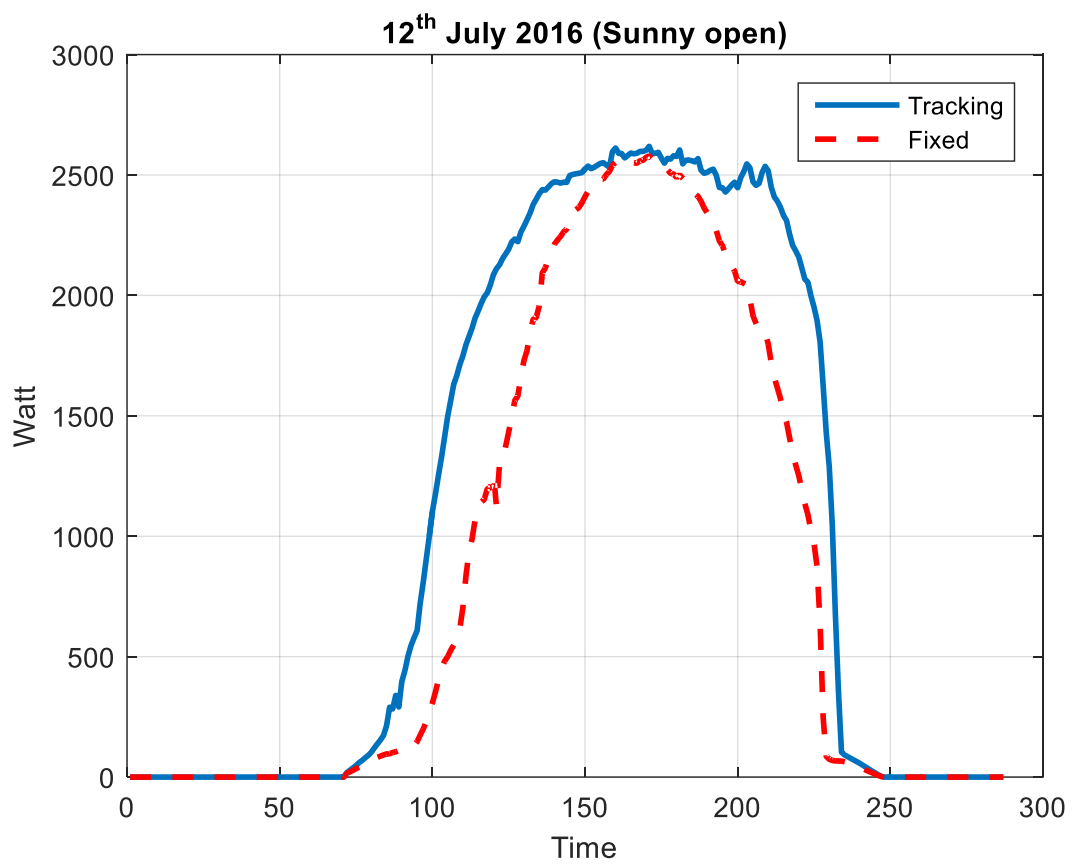

Figure 7. Tracking and fixed system generation for a sunny day on $12^{\text {th }}$ July 2016

Figure 8 shows annual power generation values of an example partly cloudy day on $4^{\text {th }}$ July 2016 . Similarly, all the generation values are higher than the fixed system when sun comes out which provides approximately $30 \%$ higher yield.

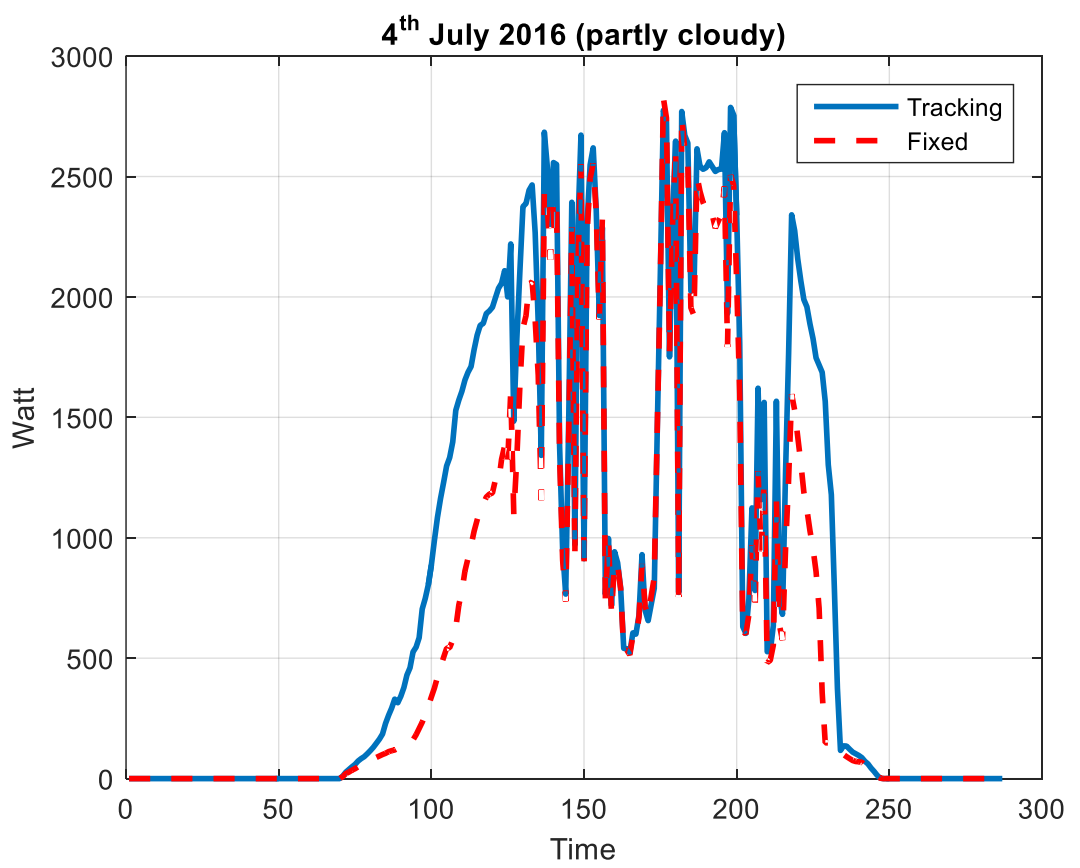

Figure 8. Tracking and fixed system generation for a partly cloudy day on $4^{\text {th }}$ July 2016

Finally, Figure 9 shows annual power generation values of an example cloudy day on $23^{\text {th }}$ July 2016. For this example, tracking and fixed systems performances are similar as expected. 


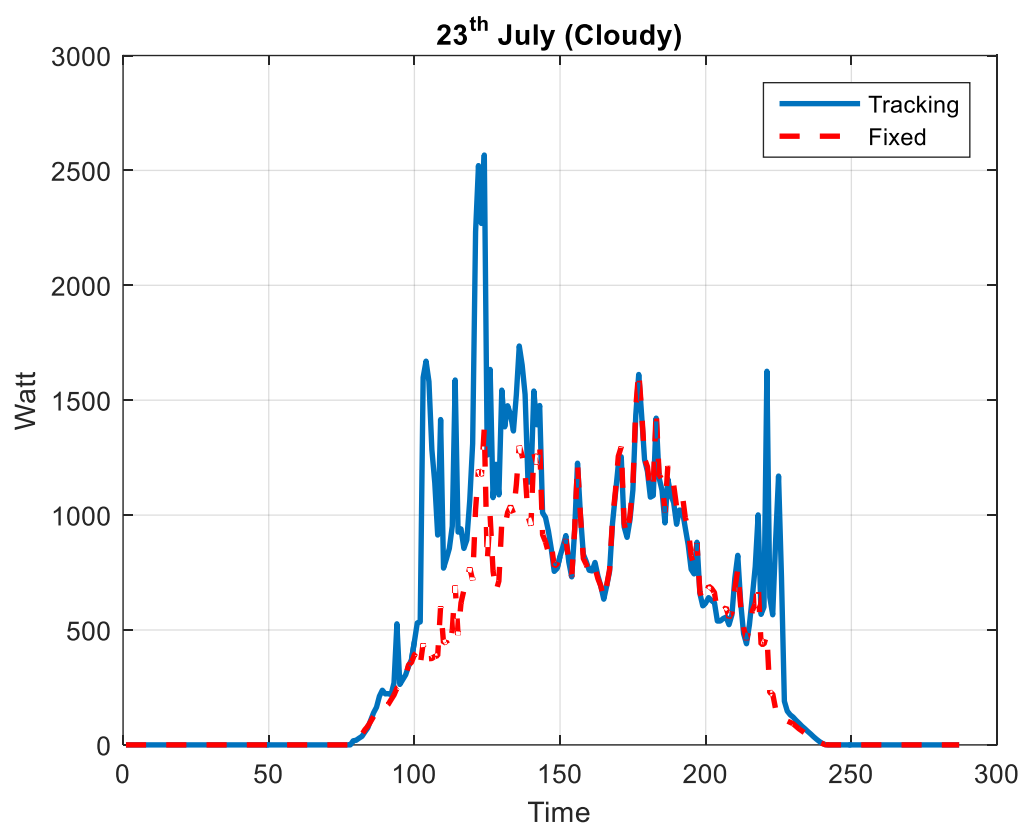

Figure 9. Tracking and fixed system generation for a cloudy day on $23^{\text {th }}$ July 2016

\section{PERFORMANCE RESULTS AND DISCUSSION}

In this section, it is aimed to make the efficiency (yield) analysis of the tracking system's for Eskisehir region. As it is seen the tracking system's power generation is always better than fixed one, but yield increase ratio is changing according to weather conditions. In order to make a fair analysis/comparison, we select the 70 days between 1 July and 30 October 2016 to figure out the ratio of sunny and cloudy days of whole year of the selected region (Eskişehir). Finally, the averaged total daily real power generation values are calculated for tracking and fixed panels as shown in Figure 9.

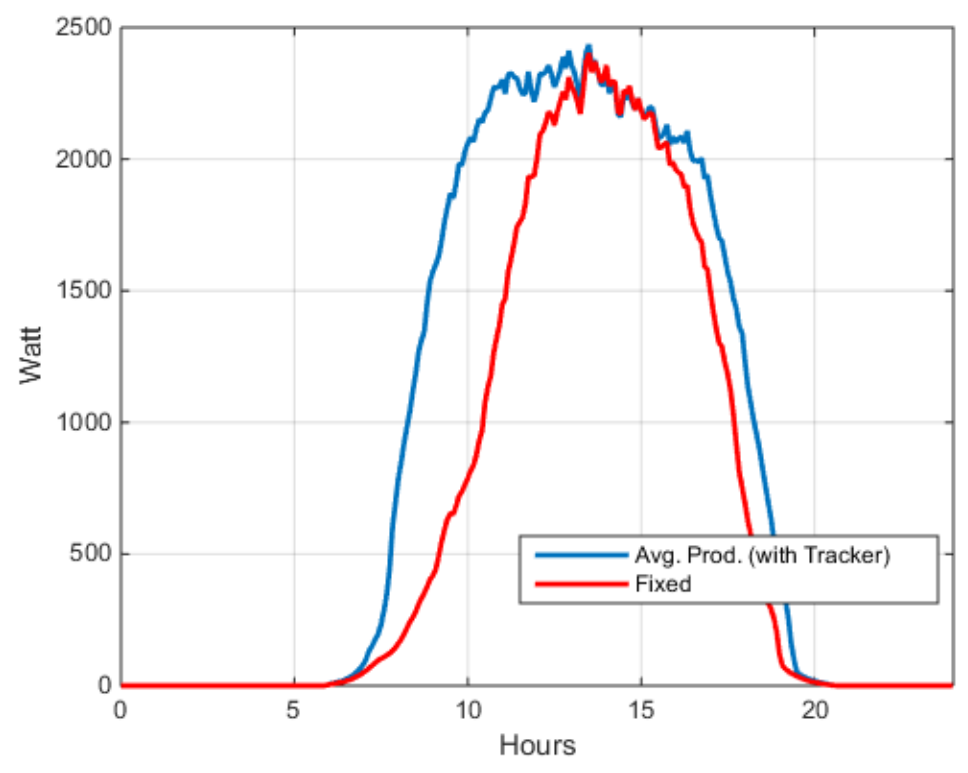

Figure 9. Averaged total daily real power generation values are calculated for tracking and fixed panels 
Tracking and fixed system's (with same $3 \mathrm{~kW}$ capacity) averaged daily generation values are given in Table 2.

Table 2. Tracking and fixed system's (with same $3 \mathrm{~kW}$ capacity) averaged daily power generation values for 70 days between 1 July and 30 October 2016 for Eskişehir region

\begin{tabular}{|c|c|c|}
\hline \multicolumn{1}{|c|}{ System } & $\begin{array}{c}\text { Averaged total daily generation } \\
(\mathbf{k W h})\end{array}$ & Yield (\%) \\
\hline 3 kW Fixed PV Panels & $\mathbf{1 6 . 0 0 8}$ & - \\
\hline 3 kW Tracking PV Panels & $\mathbf{2 1 . 3 9 2}$ & $\mathbf{3 3 . 6 3 \%}$ \\
\hline
\end{tabular}

As it seen tracking system provides approximately $33 \%$ higher yield from same capacity fixed PV panels for the Eskişehir region between 1 July and 30 October 2016.

\section{CONCLUSION}

In this study, the real instantaneous power generation values (in Watt) of sun tracking and fixed solar PV systems with same capacity are collected for 70 days between 1 July and 30 October 2016 from Eskişehir. The selected time interval is fairly figure out the ratio of sunny and cloudy days of whole year of the selected region (Eskişehir). The power generation characteristics of the sunny, cloudy and partly cloudy days are presented and compared for tracing and fixed systems.

Consequently, it is shown that the number of sunny days and maximum output temperature values (does not exceed productivity limits of the panel) of the selected region (Eskişehir) for tracking PV panels are quite convenient. It is also calculated that the considered tracking system provides approximately $33 \%$ higher electricity generation capacity than same capacity fixed PV panels between 1 July and 30 October 2016

\section{ACKNOWLEDGEMENT}

This work was supported by Anadolu University Scientific Research Projects Fund with project number: $1505 \mathrm{~F} 512$.

\section{REFERENCES}

[1] Başaran Filik Ü, Filik T, Gerek ÖN. New Electric Transmission Systems-Experiences from Turkey, Wiley, 2015.

[2] Başaran Filik Ü, Filik T. A Solar Project for Eskişehir Airport, 3rd International 100\% Renewable Energy Conference, İstanbul, Turkey, 27-29 June, 2013.

[3] Başaran Filik Ü, Ayvazoğluyüksel Ö, Filik T. A.Ü. İki Eylül Kampüsünde Güneş/Rüzgâr Verilerini İzleme Ve Hibrit Enerji Sisteminin Kurulmas1, Elektr-Mesl Gel ve Ar Der, 1, 2015, 48-54.

[4] Ayvazoğluyüksel Ö., Başaran Filik Ü. Remotely monitoring and modeling of renewable energy of a controlled home placed in A.U. İki Eylül Campus. 8th Ege Energy Symposium and Exhibition. Afyonkarahisar, 2016, Turkey.

[5] Bentaher H, Kaich H, Ayadi N, Hmouda M. B, Maalej A, Lemmer U. A simple tracking system to monitor solar PV panels, Ener Con and Manag.2014;78: 872-875. 
[6] Eke R. Senturk A. Performance comparison of a double-axis sun tracking versus fixed PV system, Sol Ener 2012; 86 :2665-2672.

[7] Senpinar A, Cebeci, M. Evaluation of power output for fixed and two-axis tracking PV arrays. App Ener, 2012; 92:677-685.

[8] Sharaf Eldin SA, Abd-ElhadyMS, Kandil HA, Feasibility of solar tracking systems for PV panels in hot and cold regions, Renew Ener; 2016, 85:228-233

[9] Dakkak M., Babeli A, Design and performance study of a PV tracking system (100W24Vdc/220Vac), Ener Proced. 2012:19: 91-95.

[10] Koussa M., Haddadi M., Saheb D., Malek A., Hadji S. Sun tracker systems effects on flat plate photovoltaic PV systems performance for different Sky States: a case of an arid and hot climate, Ener Proced;2012:18: 817-838.

[11] Lazaroiu GC, Longo M, Roscia M, Pagano M. Comparative analysis of fixed and sun tracking low power PV systems considering energy consumption. Ener Conv and Man;.2015;92:143-148.

[12] Cruz-Peragón F, Pedro J, Peláez C, Francisco A, López-García R, Palomar JM. An approach to evaluate the energy advantage of two axes solar tracking systems in Spain. Appl Energy 2011; 88:5131-5142.

[13] Serhan M, El-Chaar L. Two axis sun tracking system: comparison with a fixed system. In: Proceedings of international conference on renewable energies and power quality, Granada, Spain, 23-25 March 2010. 